$5-1-2018$

\title{
China's Anti-Corruption Crackdown and the Foreign Corrupt Practices Act
}

Daniel C.K. Chow

chow.1@osu.edu

Follow this and additional works at: https://scholarship.law.tamu.edu/lawreview

Part of the Advertising and Promotion Management Commons, Antitrust and Trade Regulation Commons, Business and Corporate Communications Commons, Business Law, Public Responsibility, and Ethics Commons, Business Organizations Law Commons, Common Law Commons, Communications Law Commons, Comparative and Foreign Law Commons, Conflict of Laws Commons, Contracts Commons, Government Contracts Commons, International Law Commons, International Trade Law Commons, Law and Politics Commons, Law and Society Commons, Legal Ethics and Professional Responsibility Commons, Litigation Commons, Organizational Behavior and Theory Commons, Organizations Law Commons, Other Law Commons, Rule of Law Commons, Securities Law Commons, and the Transnational Law Commons

\section{Recommended Citation}

Daniel C. Chow, China's Anti-Corruption Crackdown and the Foreign Corrupt Practices Act, 5 Tex. A\&M L. Rev. 323 (2018).

Available at: https://doi.org/10.37419/LR.V5.I2.2

This Article is brought to you for free and open access by Texas A\&M Law Scholarship. It has been accepted for inclusion in Texas A\&M Law Review by an authorized editor of Texas A\&M Law Scholarship. For more information, please contact aretteen@law.tamu.edu. 


\title{
ARTICLE
}

\section{CHINA'S ANTI-CORRUPTION CRACKDOWN AND THE FOREIGN CORRUPT PRACTICES ACT}

\author{
by: Daniel C.K. Chow*
}

\begin{abstract}
China's highly publicized crackdown on corruption may affect the type and number of cases in China that arise under the Foreign Corrupt Practices Act ("FCPA"), but it should not be assumed that the crackdown will necessarily lead to fewer FCPA prosecutions. Although there is some overlap of the goals of China's corruption crackdown and the goals of the FCPA, China's crackdown also serves important goals of the ruling Communist Party. The main goal of the current crackdown is to reinforce the Party's power by targeting enemies and rivals of the current leadership. The crackdown is not aimed at prohibiting bribes given to foreign officials for the purpose of obtaining business; however, the FCPA is aimed at proscribing these types of bribes. As a result, while the crackdown may deter some types of FCPA cases from arising in China, other types of cases will be unaffected or may even increase.
\end{abstract}

\section{TABle of Contents}

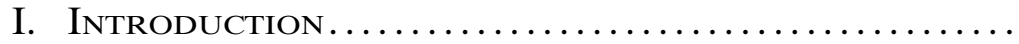

II. Catching "Tigers and Flies" ................. 325

III. EFFeCt OF THE CRACKDOWN ON THE FCPA IN

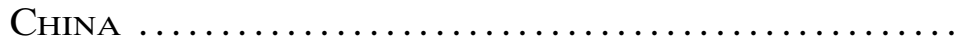

A. Government and Party Officials as Targets of the Crackdown.................................

B. Money or Property Under PRC Law and "Anything of Value" Under the FCPA .....................

C. State-Owned Enterprises and Corrupt Activities Abroad ......................................

IV. Conclusion ..................................

\section{INTRODUCTION}

In China's most prosperous cities, high-end restaurants now sit eerily quiet in the evenings; just several years ago they were bustling with the boisterous sounds of lavish, liquor-fueled banquets attended

* Frank E. and H. Virginia Bazler Chair in Business Law, The Ohio State University Michael E. Moritz College of Law. The Author lived and worked in China as in-house counsel at a multinational company's China headquarters and dealt first hand with many of the issues discussed in this Article. The Author thanks the participants at the Texas A\&M FCPA Conference held on October 12, 2017 for their comments and suggestions. Joshua McCarroll, a rising $2 \mathrm{~L}$ at the Moritz College of Law, provided valuable research assistance for this Article. 
by both government officials and their business associates. ${ }^{1}$ Luxurious night clubs and karaoke bars, once packed with officials, have now shuttered their doors. ${ }^{2}$ The high-end food and entertainment industry-that used to generate thousands of dollars every evening ${ }^{3}$ - is now struggling to find alternative sources of revenue in response to the government's visible crackdown on government spending. These are some of the most obvious signs of China's crackdown on corruption. Other, more ominous signs are the highly publicized trials of corrupt government and business officials receiving draconian criminal penalties for crimes described in lurid detail of bribery, extortion, and embezzlement. ${ }^{4}$ All over China, the effects of the Chinese government's crackdown on government corruption are visible.

Not only has the anti-corruption campaign shut down the more ostentatious consumption habits of government and Party officials, the crackdown also appears to have a chilling effect on illegal conduct. In every corner of China's vast bureaucracy, officials are fearful and are adopting a cautious attitude as officials openly talk about the risks of professional and personal ruin that can result from accepting an illegal bribe. ${ }^{5}$ One might assume that China's nationwide campaign against corruption, which has instilled fear in many of China's bureaucrats, might also lead to fewer cases under the U.S. Foreign Corrupt Practices Act ("FCPA") 6 due to Chinese officials being on high alert and therefore less willing to take the risk of accepting bribes. As discussed below, some types of FCPA cases appear to be affected by the crackdown, while other types of cases have not been affected; further, the unaffected cases could increase in number as corrupt conduct migrates from high-risk to low-risk areas. Although these may be areas of lower risk in China's current political climate, these are risks that nonetheless fall squarely within the prohibitions of the FCPA, which is jointly enforced by the U.S. Department of Justice ("DOJ") and the U.S. Securities and Exchange Commission ("SEC"). ${ }^{7}$

This Article will discuss three areas in which the current crackdown will likely not deter FCPA cases from arising. The first group of cases

1. See Mamta Badkar, China's President Has Only Begun to Take Down the Tigers and Swat the Flies in His Historic Corruption Crackdown, Bus. Insider (July 26, 2014, 5:11 PM), http://www.businessinsider.com/chinas-corruption-crackdown2014-7 [https://perma.cc/98GK-6UJQ].

2. See Edward Wong, Red Lights Dim in China's Sin City, N.Y. Times (Mar. 6, 2014), https://www.nytimes.com/2014/03/07/world/asia/red-lights-dim-in-chinas-sincity.html?_r=0 [https://perma.cc/R2BM-LLQU].

3. See id.

4. See Andrew Jacobs, Chinese Trial Reveals Vast Web of Corruption, N.Y. TIMES (Nov. 3, 2009), http://www.nytimes.com/2009/11/04/world/asia/04crimewave.html [https://perma.cc/B4FS-G3QM].

5. This observation is based upon the Author's discussion with various lawyers and officials in China, as well as the Author's own personal observations in China.

6. Foreign Corrupt Practices Act of 1977, 15 U.S.C. $\S \S 78 \mathrm{dd}-1$ to $78 \mathrm{ff}$ (2012).

7. See id. 
concerns the conduct of persons considered to be private individuals under People's Republic of China ("PRC") law, i.e. persons who are not Party or government officials. ${ }^{8}$ Although these persons are not considered to be Party or government officials, who are the focus of China's crackdown, some private persons might be considered to be "foreign officials" within the meaning of the FCPA whose conduct might trigger FCPA liability. ${ }^{10}$ In other words, while certain private persons may not be the focus of China's crackdown, the same persons could be the target of FCPA actions. The second group of cases concern the giving of a benefit in a form other than "money or property" 11 to a government or Party official. ${ }^{12}$ The salient provision of the PRC Criminal Law that proscribes bribery of government or Party officials prohibits the giving of "money or property" to such officials; however, the statute does not mention benefits in other forms. ${ }^{13}$ By contrast, the FCPA not only proscribes the giving of money or property, but also the giving of "anything of value," a much broader term that reaches indirect and intangible benefits. ${ }^{14}$ Cases in which intangible benefits are given to Party or government officials, even those which are not proscribed by PRC's Criminal Law, might still fall within the proscription of the FCPA. ${ }^{15}$ The third type of case involves conduct that occurs outside of China where China's state-owned enterprises ("SOEs") are aggressively engaged in various investments and business operations. ${ }^{16}$ Although China's crackdown does not focus on activities occurring outside of China where SOEs can operate with little oversight, the FCPA could capture the conduct of China's SOEs in foreign countries under some circumstances. ${ }^{17}$

\section{Catching "Tigers and Flies"}

Although China's current crackdown on corruption began with the ascendancy of Xi Jinping to the office of the President of the PRC in $2012,{ }^{18}$ China has suffered from persistent problems of corruption

8. See infra Part III.A.

9. The FCPA proscribes giving bribes to "foreign officials" for the purpose of obtaining or retaining business. See 15 U.S.C. § 78dd-1(a)(1).

10. See infra Part III.A.

11. Article 385 of the People's Republic of China ("PRC") Criminal Law specifically refers to the giving of "money or property" as bribes. Many other provisions of the PRC Criminal Law also refer explicitly to the illegal giving and receipt of "money or property." See, e.g., Criminal Law of the People's Republic of China [hereinafter PRC Criminal Law], art. 385 (promulgated by the Nat'l People's Cong., Mar. 14, 1997, effective Oct. 1, 1997).

12. See infra Part III.B.

13. PRC Criminal Law, supra note 11, art. 385.

14. 15 U.S.C. $\S 78 \mathrm{dd}-1(\mathrm{a})$.

15. See id.

16. See infra Part III.C.

17. See 15 U.S.C. $\$ 78 d d-1(a)$.

18. See Daniel C.K. Chow, How China's Crackdown on Corruption Has Led to Less Transparency in the Enforcement of China's Anti-Bribery Laws, 49 U.C. DAvis 
since the early days of the current regime, founded in $1949 .{ }^{19}$ As early as 1989 , Party elders warned that corruption will ruin the Party. ${ }^{20}$ Since its founding, the PRC has periodically implemented anti-corruption campaigns, ${ }^{21}$ but the current crackdown appears to be unprecedented in both scope and severity. President Xi has warned that he intends to catch both "tigers and flies," that is, both high- and lowlevel officials. ${ }^{22}$ In the past, corruption campaigns have been criticized for using a few symbolic cases brought against minor officials to satisfy public perception while allowing high-level officials to operate with impunity. ${ }^{23}$ The most sensational recent case for PRC observers was that of Zhou Yong Kang, the retired head of one of China's most powerful organs, the Ministry of Public Security, which oversees China's police and prisons. ${ }^{24}$ After a brief trial, Zhou was sentenced to life imprisonment for graft. ${ }^{25}$ This case was significant because, in addition to Zhou's government post, he was also a member of China's Politburo. ${ }^{26}$ This group is the elite inner core of the Communist Party consisting of about twenty or so cadres representing China's highest echelons of power. ${ }^{27}$ Until Zhou's case, no one in China's Politburo had ever been found guilty in a corruption scandal and many assumed that such persons were beyond the reach of the law for ordinary economic crimes, such as graft and bribery, and subject only to crimes of treason. ${ }^{28}$ Zhou's case seems to indicate that under the current campaign, no one is to be spared. ${ }^{29}$

L. Rev. 685, 690 (2015) [hereinafter Chow, China's Crackdown on Corruption]. Xi's real power stems from his position as General Secretary of the Communist Party, the highest position in the Party, and Chairman of the Central Military Commission, which controls the PRC military. Xi acquired these positions before he became President. His position as President of the PRC is a ceremonial position that has no real power. See Daniel C.K. Chow, The Legal System of the People's Republic of China in a Nutshell 103 (3d ed. 2015) [hereinafter Chow, Legal Systems of China].

19. See Chow, Legal Systems of China, supra note 18, at 54-55.

20. Chow, China's Crackdown on Corruption, supra note 18, at 690.

21. Id. at 687 .

22. Tania Branigan, Xi Jinping Vows to Fight 'Tigers' and 'Flies' in Anti-Corruption Drive, Guardian (Jan. 22, 2013, 12:44 PM), http://www.theguardian.com/world/ 2013/jan/22/xi-jinping-tigers-flies-corruption [https://perma.cc/U538-B2YL].

23. Chow, China's Crackdown on Corruption, supra note 18, at 687.

24. Julie Makinen, Ex-Security Czar Gets Life Term as China Graft Trial Comes to Quiet End, L.A. TIMEs (June 11, 2015, 9:30 AM), http://www.latimes.com/world/asia/ la-fg-former-china-security-chief-sentenced-20150611-story.html [https://perma.cc/ BY9D-3G9G].

25. Id.

26. $I d$.

27. See Chow, Legal System of China, supra note 18, at 128.

28. See Chow, China's Crackdown on Corruption, supra note 18, at 696.

29. Zhou was retired and no longer a Politburo member when he was convicted. So, the current campaign has not ensnared any current members of China's highest elite. This might be the last line that has not yet been crossed by the current campaign. 
Xi's campaign against official corruption serves at least two important purposes. First, the Party has long been concerned about corruption because of the perception that corruption undermines its legitimacy and its claim to power. ${ }^{30}$ The Communist Party frequently trumpets its unique place in China's history and its tortuous rise against all odds to power. ${ }^{31}$ At various times in its history, the Party was besieged and faced extinction. ${ }^{32}$ During the turbulent and chaotic 1920s and 1930s, the ruling Nationalist government ruthlessly hunted members of the Party as "bandits" and killed them in the streets by beheadings and shootings. ${ }^{33}$ The Party prevailed against the Nationalist government, a vastly superior enemy supplied with generals, military weapons, and money from the United States ${ }^{34}$ that carried U.S. hopes for a republican China that would serve as a counterweight in Asia to the rise of the Soviet Union. ${ }^{35}$ In many ways, just as the Party believes emperors of Imperial China ascended to the throne by celestial authority through the "mandate of heaven," the Party also believes that it ascended to leadership as a matter of destiny. ${ }^{36}$ These sentiments are embodied in the preamble to the PRC Constitution, which states that "twentieth century history has shown that only the Communist Party can save the Chinese people and lead them to happy lives." 37 This heroic portrayal of the Party is undermined by the sordid tales of greed and debauchery by Party members. Corruption demeans the Party in the eyes of the public, tarnishes its heroic stature, and undercuts its claim to legitimacy as the only capable leader of the people.

The anti-corruption campaign may also serve a more personal goal for President Xi. Critics claim that $\mathrm{Xi}$ is able to rid himself of enemies by purging them through the guise of corruption charges. ${ }^{38}$ These critics argue that the true goal of the campaign is not to rid the Party of corruption-instead, it is to rid the State of Xi's enemies and rivals. ${ }^{39}$ According to this view, once these goals are accomplished, the fervor

30. See Daniel A. Bell, Why China's Leaders See Corruption as a Mortal Threat, Huffington Post (Feb. 17, 2015), http://www.huffingtonpost.com/daniel-a-bell/ china-corruption-threat_b_6699410.html [https://perma.cc/JKK6-PM5M].

31. See Chow, Legal System of China, supra note 18, at 120.

32. See id. at 121.

33. See id. at 122.

34. See id. at 121.

35. See id. at 13.

36. See id. at 121.

37. See id. at 120.

38. See Javier C. Hernández, China Corruption Fight Extends to Top Officials in Beijing and Shanghai, N.Y. Times (Nov. 11, 2015), https://www.nytimes.com/2015/11/ 12/world/asia/china-crackdown-corruption-beijing-shanghai-ai-baojun-lu-xiwen.html? mcubz=3 [https://perma.cc/RS2Y-FFPE].

39. See id. 
of the anti-corruption campaign will begin to fade, and corruption may once again be on the rise. ${ }^{40}$

\section{Effect of the Crackdown on the FCPA in ChinA}

China's anti-corruption campaign may have an impact on the number of FCPA cases that arise in China, but not on every type of case nor in every instance. To understand how FCPA cases will be affected, we first examine China's Criminal Law, which is the legal centerpiece of the crackdown on government corruption. The anti-bribery provision of the Criminal Law of the People's Republic of China ("PRC Criminal Law") is contained in Article 385, which states as follows: "Any State functionary who, by taking advantage of his position, extorts money or property from another person, or illegally accepts another person's money or property in return for securing benefits for the person shall be guilty of acceptance of bribes." ${ }^{41}$ In addition to Article 385, other articles of the PRC Criminal Law also indicate a focus on state functionaries and officials of state-owned enterprises. ${ }^{42}$

Article 385 focuses on "state functionaries" and bribery by state officials. ${ }^{43}$ A different provision of the PRC Anti-Unfair Competition Law proscribes commercial bribery, i.e. bribes given or received by private persons to business operators for the purpose of obtaining a business advantage. ${ }^{44}$ Official corruption is a more serious offense than commercial bribery, as it falls under the PRC Criminal Law, which is viewed as fundamental law, while commercial bribery falls under an economic law, which is considered secondary ${ }^{45}$ The penalties for official corruption are far more serious than penalties for commercial bribery. ${ }^{46}$

40. See id.

41. PRC Criminal Law, supra note 11, art. 385.

42. See, e.g., id. art. 382 (embezzlement by state functionaries); art. 384 (misappropriation of public funds by state functionaries); art. 388 (extortion by state functionaries); art. 387 (acceptance of bribes by state organs and state owned enterprises); art. 396 (theft of state assets by state organs and state owned enterprises).

43. Id. art. 385.

44. See Law Against Unfair Competition of the People's Republic of China [hereinafter PRC Anti-Unfair Competition Law] (promulgated by Order No. 10 of the President of the People's Republic of China, Sept. 2, 1993, effective Dec. 1, 1993), art. 8.

45. Criminal Law is considered one of most important laws in the PRC; it is considered to be a "basic law" and was passed by the National People's Congress, the legislature in the PRC. A law such as the Anti-Unfair Competition Law, passed by a committee of the National People's Congress, is viewed as "other laws" of less importance. For a hierarchy of laws and legal norms, see ChOw, Legal System of ChinA, supra note 18 , at $159-60$.

46. China's commercial bribery penalty consists of a fine between 10,000 yuan and 200,000 yuan and confiscation of illegal earnings. In contrast, the criminal penalty for official corruption can include administrative sanctions, confiscation of property, and/ or a prison term of one year to life imprisonment, depending on the amount embez- 


\section{A. Government and Party Officials as Targets of the Crackdown}

The term state functionary is not defined in the PRC Criminal Law, but other provisions refer to a "functionary of a state organ" 47 and a "functionary of a relevant competent department of the State." 48 These terms indicate that a state functionary is a government official. The term could also refer to a Communist Party official because the Party sees itself as representing the State. ${ }^{49}$ Moreover, in the vast majority of cases, a government official is also a Party official. ${ }^{50}$ The Party installs its members in all key government positions so the Party can control the State. ${ }^{51}$ Most government officials and all high-ranking government officials are also Party officials. ${ }^{52}$ The Party and the government are fused together at various points in the Party and government hierarchy. ${ }^{53}$ The Party body and the government body have exactly the same membership. ${ }^{54}$

The focus of Article 385 on Party and government officials is consistent with the stated purposes of the crackdown on corruption. The campaign is concerned primarily with official corruption by Party and government officials and is not focused on private persons engaged in commercial bribery. ${ }^{55}$ The crackdown is designed to protect the reputation of the Party from criticism, embarrassment, and ridicule. The campaign is not focused on cases of commercial bribery involving non-members of the Party, especially small-scale corruption cases by petty criminals. ${ }^{56}$ Commercial bribery is an economic crime that does not directly threaten the Party's reputation. While such persons are outside of the scope of the anti-bribery provisions of the PRC Criminal Law and the crackdown on corruption, they may be within the scope of persons covered under the FCPA.

The FCPA proscribes bribes paid to foreign officials to obtain or retain business. ${ }^{57}$ The FCPA defines foreign officials to include an em-

zled and the seriousness of the circumstances. See PRC Anti-Unfair Competition Law, supra note 44, Ch. 3, art. 22; PRC Criminal Law, supra note 11, art. 383.

47. PRC Criminal Law, supra note 11, art. 238.

48. Id. art. 403.

49. See Chow, Legal Systems of China, supra note 18, at 120 (explaining that the Communist Party views itself as the leader of the Chinese people).

50. See id. at 133.

51. See id.

52. For example, the Central Military Commission ("CMC") controls the armed forces of the PRC and is one of the most powerful and important entities in China. The Central Military Commission of the Party and the Central Military Commission of the PRC are two separate bodies, but the membership has been entirely the same since 1982. Xi Jinping is the current chair of the CMC. See id. at 129.

53. Id

54. Id.

55. See Robber Barons, Beware, Economist (Oct. 22, 2015), https://www.econo mist.com/news/china/21676814-crackdown-corruption-has-spread-anxiety-among-chi nas-business-elite-robber-barons-beware [https://perma.cc/RY3F-B2CN].

56. See id.

57. 15 U.S.C. $\S 78 d d-1(a)(1)$. 
ployee of a foreign government or an instrumentality thereof and any person acting in an official capacity on behalf of a foreign government. ${ }^{58}$ An instrumentality of the PRC government includes SOEs, which are companies that are owned in whole or in part by the State. ${ }^{59}$ State-controlled enterprises are also considered to be instrumentalities of the State. ${ }^{60}$ The DOJ and SEC have indicated that it considers employees of SOEs to be foreign officials. ${ }^{61}$ This expansive position taken by the DOJ and SEC could mean that even low-level employees of an SOE could be foreign officials for purposes of the FCPA. ${ }^{62}$

Under this definition, suppose that a sales agent of the China business entity of a multi-national company ("MNC") in the chemicals industry approaches a purchasing agent, a low-level employee, of an SOE about the potential sale of chemical materials. The purchasing agent is indifferent about where to purchase the products. It makes little or no difference to the purchasing agent if he purchases the product from one seller as opposed to another; all of the sellers are offering similar products at similar prices. In order to induce the purchasing agent to buy the products, the sales agent offers to give the purchasing agent a small kickback of several hundred to several thousand dollars. The payment will go to the personal account of the purchasing agent and will not be shared with anyone else in the SOE. The sales agent will also receive a benefit from the completed sale. The sales agent of the $\mathrm{MNC}$ receives credit for the sale and might then also receive a year-end bonus or a promotion for good performance. Both the purchasing agent and the sales agent can benefit personally from the kickback. Such petty corruption occurs in China on a daily basis and is tolerated by most people who are resigned to accept that petty corruption is a regular part of doing business in China. ${ }^{63}$ This type of petty corruption, involving a few hundred or thousand dollars, is not the type of corruption involving Party or government officials that is the focus of China's anti-corruption campaign. ${ }^{64}$ The DOJ and SEC could, however, view this transaction as a violation of the FCPA if they consider it to be a payment of a bribe by the MNC's China business entity to a foreign official for the purpose of obtaining business. The low-level sales agent is an employee of a SOE and therefore may be considered a foreign official by the DOJ and SEC. The sales agent's payment of the kickback was to a foreign official to obtain business, i.e., the sale of the products by the MNC to the SOE. Cases

58. $I d . \S 78 \mathrm{dd}-1(\mathrm{f})(1)$.

59. See Daniel Chow, China Under the Foreign Corrupt Practices Act, 2012 Wis. L. Rev. 573, 581 (2012).

60. See id.

61. Id. at 582 .

62. Id. at 583 .

63. See Jie Chen \& Bruce J. Dickson, Allies of the State: China's Private Entrepreneurs and Democratic Change 111 (2010).

64. See Barons, supra note 55. 
of petty corruption, while not the focus of the anti-corruption campaign, may continue to trigger liability under the FCPA.

A special situation under current scrutiny in the PRC concerns pharmaceutical companies providing kickbacks to doctors. Many doctors in China work for state hospitals, which are responsible for delivering medical services to the majority of people in China ${ }^{65}$ While there are some private hospitals in China, the majority of people look to low-cost state hospitals for their medical services. ${ }^{66}$ Doctors who work in state hospitals are notoriously poorly compensated and work under harsh conditions. ${ }^{67}$ It is common knowledge that doctors in state hospitals can receive additional income in the form of kickbacks from pharmaceutical companies. ${ }^{68}$ When a doctor prescribes a medication to a patient, the manufacturer of the medication makes a payment (i.e., a kickback) to the doctor ${ }^{69}$ Everyone in China is aware of this practice, but it is tolerated because doctors are so poorly compensated. Without them, doctors may leave their jobs with state hospitals either to work in private hospitals or to switch careers. ${ }^{70}$ Eliminating the need for kickbacks by increasing compensation for doctors through official channels is not an easy goal to achieve. In addition to budget constraints, paying doctors on a scale similar to what doctors are paid in other Asian countries runs into political opposition. In China, doctors are viewed as servants of the people and it is not feasible in China's current political climate for the State to give servants of the people the type of high salaries that are paid to doctors in other Asian countries. ${ }^{71}$ As a result, for decades PRC authorities have simply ignored the kickbacks that doctors receive from pharmaceutical companies as a practical necessity to keep the system intact. ${ }^{72}$

China's tolerant attitudes towards kickbacks were tested when a massive \$500 million kickback scheme involving Glaxo Smith Kline

65. Karen Eggleston et al., Comparing Public and Private Hospitals in China: Evidence from Guangdong, BMC HeAlTH SERvs. Res. 3-5 (2010), https://www.researchgate.net/profile/Mingshan_Lu/publication/42440309_Comparing_Public_and_Private_ Hospitals_in_China_Evidence_from_Guangdong/links/Ofcfd5123ce374dcd7000000/ Comparing-Public-and-Private-Hospitals-in-China-Evidence-from-Guangdong.pdf [https://perma.cc/WZ7V-VBCQ].

66. See id.

67. Joe McDonald, Case Shines Light on China's Medical Bribery, Morning J. (Aug. 2, 2013), http://www.pressreader.com/usa/the-morning-journal-lorain-oh/201308 02/281956015411326 [https://perma.cc/QTC3-2NUJ].

68. $I d$.

69. Id.

70. See id.

71. See Emily Rauhala, Why China's Doctors Are Getting Beat Up, Trme (Mar. 7, 2014), http://time.com/15185/chinas-doctors-overworked-underpaid-attacked/ [https:// perma.cc/XYN5-DKVK].

72. See Physician, Heal Thyself: The Cost of Medicine, Economist (Feb. 1, 2014), https://www.economist.com/news/china/21595431-medicines-are-over-prescribed-andoverpriced-physician-heal-thyself [https://perma.cc/G2G8-GAY4] [hereinafter The Cost of Medicine]. 
("GSK"), a UK-based pharmaceutical company, was uncovered in $2014 .^{73}$ Chinese authorities discovered that GSK was funneling nearly half a million dollars in cash to doctors and state hospitals through various third party entities, such as travel agencies, to induce them to prescribe GSK's pharmaceuticals. ${ }^{74}$ While PRC authorities had tolerated kickbacks to doctors for years, this was an organized scheme that involved hundreds of millions of dollars and that, when exposed, embarrassed the PRC by the sheer size of the bribery scheme. ${ }^{75}$ As a result, in 2017, the PRC passed legislation to eliminate kickbacks to doctors. ${ }^{76}$ Over the past twenty years, similar legislation has been regularly enacted, but because of the prevailing tolerant attitudes of the PRC authorities, the legislation prohibiting kickbacks has never been enforced. ${ }^{77}$

The current situation involving medical kickbacks seems to create a political dilemma for the Party, but this dilemma is quite different from the prototypical case involving corruption by government officials. The kickbacks given to doctors are less about greed and avarice and more about a practical and necessary solution to the problem of low compensation for doctors. The State pays low salaries to doctors based upon the fiction that as state workers in a socialist health care system, doctors are willing to work for low salaries in order to serve the people. ${ }^{78}$ As everybody in China knows, this is a self-serving fiction of the Communist Party and does not accurately reflect the attitudes of most doctors. ${ }^{79}$ Paying doctors more will involve higher state expenditures and will expose the fiction of the altruistic and selfless doctor, which are both undesirable outcomes for the Party. At present, multinational pharmaceutical companies are providing subsidies to doctors and hoping that maintaining the status quo will allow the health care system to continue to function while the State finds a viable solution to the problem of low compensation and difficult work conditions. In other words, although the GSK case embarrassed the Party, the Party still has an incentive to continue to tolerate kickbacks

73. Keith Bradsher \& Chris Buckley, China Fines GlaxoSmithKline Nearly $\$ 500$ Million in Bribery Case, N.Y. TIMEs (Sept. 19, 2014), https://www.nytimes.com/2014/ 09/20/business/international/gsk-china-fines.html [https://perma.cc/PVR8-TQ5C].

74. Id.

75. $I d$.

76. See Notice of the National Health and Family Planning Commission on Printing and Distributing the "Provisions on the Establishment of Bad Record of Commercial Bribery in the Area of Medical Supplies and Pharmaceuticals Purchase and Sales", Nat'l Health \& Fam. Plan. Commission (Dec. 27, 2013), http://www.nhfpc.gov.cn/ fzs/s3577/201312/ef92cb05dee341a18fff7b3e00eb1156.shtml [https://perma.cc/5SASW5BE] (translated from Chinese). Circulars 49 and 163 issued by the National Health and Planning Commission.

77. See The Cost of Medicine, supra note 72.

78. This observation is based on the Author's own experience working as a lawyer in China.

79. This observation is based on the Author's own experience in China. 
to doctors, at least temporarily, while searching for a long-term solution to the problem of affordable health care.

While kickbacks to doctors create a political and social dilemma in China, the DOJ and SEC might find that MNC pharmaceutical companies are liable under the FCPA for making the kickbacks. State hospitals are instrumentalities of the PRC government; doctors and administrators who work for state hospitals therefore qualify as foreign officials under the FCPA. ${ }^{80}$ When a pharmaceutical company gives a kickback to induce a doctor to prescribe its medications, the kickback might qualify as a bribe given by a United States entity to a foreign official to obtain business under the FCPA. As the GSK case has exposed the schemes involved in these cases and the widespread practice of kickbacks in the medical field, the DOJ and SEC have now been alerted to the problem and may be on the lookout for such new cases. FCPA investigations involving kickbacks given by MNC pharmaceutical companies to doctors to induce them to prescribe the MNC's medications might increase in the near future. Cases concerning doctors and pharmaceutical companies are examples of the types of cases that might not be the subject of China's crackdown on corruption, but that nonetheless may fall within the FCPA.

\section{B. Money or Property Under PRC Law and "Anything of Value" Under the FCPA}

Article 385, the anti-bribery provision in the PRC Criminal Law, prohibits the giving of "money or property" to state functionaries. ${ }^{81} \mathrm{~A}$ separate provision creates a duty on the part of a state functionary to identify the sources of his property. Article 395 states: "Where the property or expenditure of any State functionary obviously exceeds his legitimate income, and the difference is huge, he shall be ordered to explain the sources. If he fails to do so, the difference shall be determined as illegal income ...."82 This provision was enacted to deal with the common problem of PRC officials who own expensive apartments and drive luxury cars, even though they receive modest salaries. The public views these officials with both cynicism and resignation. ${ }^{83}$ This provision is designed to deter Chinese state officials from flaunting their illegally acquired wealth by creating a duty for officials to account for levels of wealth that appear to exceed their lawful sources of income. ${ }^{84}$

80. See supra text accompanying notes $65-70$.

81. PRC Criminal Law, supra note 11, art. 385.

82. Id. art. 395 .

83. This observation is based on the Author's own experience. Many people in China hold the cynical belief that all Party and government officials are corrupt-the only question is one of degree.

84. Note that the provision creates an incentive to hide one's wealth but does not necessarily create an incentive to avoid accumulating illegal wealth in the first place. 
This provision and others ${ }^{85}$ show a focus on tangible financial assets acquired and owned by state officials. In contrast, giving benefits to a state functionary that are not tangible financial assets is outside the scope of these laws and therefore not prohibited. The Party does not seem to find intangible benefits to be a concern.

Under the FCPA, however, it is illegal to make a payment of money, gift, or "anything of value." 86 The term "anything of value" can encompass gifts of an intangible nature and is not limited to money or property. ${ }^{87}$ Cases that involve intangible benefits might trigger liability under the FCPA. ${ }^{88}$ For example, suppose that a U.S.based MNC finds that its intellectual property ("IP") has been stolen. The MNC sends representatives to PRC enforcement authorities to lodge a complaint. The authorities inform the MNC that it must submit a report from a state-approved technology consulting company to confirm that the alleged stolen information qualifies as a trade secret under PRC law. ${ }^{89}$ The enforcement authority will refuse to act without such a report because the authority does not want to act outside the scope of its jurisdiction and does not want to bring an enforcement action that has no merit. ${ }^{90}$ The PRC's enforcement authority is in no position to make an informed decision on whether to proceed. ${ }^{91}$ The PRC authority's expertise is in law enforcement, not in intellectual property, and trade secrets can be highly complex and technical. ${ }^{92}$ As a result, the enforcement authority demands that the MNC submit a report from a qualified state technology consulting company that the alleged stolen information qualifies as a trade secret. ${ }^{93}$ Sometimes, the chief of the enforcement authority might direct the MNC to a stateowned technology consulting company that is owned by or under the supervision of a relative or friend. ${ }^{94}$ Once the MNC obtains the report and files it, the authority can move forward with an enforcement action and is protected if the defendant claims that the enforcement authority acted improperly.

In China today, there are many state-owned or approved technology-consulting companies all vying for business in the highly competitive IP-enforcement field. If the MNC hires the company recommended by the chief of the enforcement bureau, the DOJ and SEC might view the hiring as providing an intangible benefit to the

85. See PRC Criminal Law, supra note 11, art. 385.

86. 15 U.S.C. $\S 78 \mathrm{dd}-1(\mathrm{a})(1)$.

87. See, e.g., United States v. Marmolejo, 89 F.3d 1185, 1191-92 (5th Cir. 1996).

88. See id. at 1192-93.

89. See Daniel C.K. Chow, Navigating the Minefield of Trade Secrets Protection in China, 47 Vand. J. Transnat'L L. 1007, 1032 (2014).

90. See id. at 1031.

91. See id. at 1032.

92. Id.

93. $I d$.

94. See id. at 1035. 
enforcement bureau in exchange for the bureau agreeing to bring an enforcement action. Article 385 of the PRC Criminal Law proscribes the giving of money or property to the state official, but in this scenario the MNC never gives the official any payments. ${ }^{95}$ The MNC will pay fees to the consulting company owned or managed by the relative, and the relative does not give any part of the payment to the state official. The state official benefits by having helped a family member, which violates no PRC law. In contrast, the DOJ and SEC might see this intangible benefit as something of value which was given to a state official for the purpose of obtaining the enforcement action that will help the MNC retain business. This view could trigger an FCPA investigation.

Many people in China today would find that the chief of the enforcement bureau did nothing ethically or legally wrong in recommending a company owned by a relative to the MNC. Many people would believe that it is natural and understandable for the chief to want to help a relative, especially when he received no money or property in return. The Criminal Law itself clearly states that an illegal bribe occurs only when money or property is given to an official, ${ }^{96}$ leaving the door open for officials to derive intangible benefits in exchange for the exercise of power. Officials in the PRC may also see nothing wrong with asking a MNC to provide an internship for a child or relative. ${ }^{97}$ Although this situation is lawful under PRC law, providing the internship might be unlawful under the FCPA if the MNC receives business in return..$^{98}$

\section{State-Owned Enterprises and Corrupt Activities Abroad}

The focus of Xi's crackdown is on official corruption occurring in China that exposes the Party to embarrassment, contempt, and ridicule. Corrupt activities by PRC officials that occur in a foreign country are less visible and of less concern to China's population and to the Party. For this reason, state-owned enterprises might feel emboldened to act corruptly in pursuing business opportunities abroad as they do not fear prosecution for corruption in the PRC.

China is in the midst of an ambitious expansion of its business operations abroad, especially in developing countries ${ }^{99}$ such as those in Africa, where corruption was rampant long before China started do-

95. See PRC Criminal Law, supra note 11, art. 385.

96. See sources cited supra note 42.

97. See Antoine Gara, JPMorgan Agrees to Pay \$264 Million Fine for 'Sons and Daughters' Hiring Program in China, Forbes (Nov. 17, 2016, 4:44 PM), https://www .forbes.com/sites/antoinegara/2016/11/17/jpmorgan-agrees-to-pay-264-million-finefor-sons-and-daughters-hiring-program-in-china/\#62d410e65688 [https://perma.cc/ FRS4-HTPA].

98. Id.

99. See, e.g., Clifford Krauss \& Keith Bradsher, China's Global Ambitions, Cash and Strings Attached, N.Y. TIMEs (July 24, 2015), https://www.nytimes.com/2015/07/ 
ing business there. ${ }^{100}$ For the last two decades, China and Africa have been forging closer business ties. For example, in 2000, China and Africa formed the Forum on China-Africa Cooperation, a vehicle for business cooperation between China's state-owned enterprises and governments in Africa. ${ }^{101}$ In November 2006, China announced that it was creating a China-Africa development fund worth $\$ 5$ billion to support Chinese investment in Africa. ${ }^{102}$ During the Beijing Summit of 2006, China also announced the creation of an aid package to Africa consisting of grants and interest-free loans. ${ }^{103} \mathrm{~A}$ few months after the Beijing Summit, the African Development Bank held its annual board meeting in Shanghai. ${ }^{104}$ These developments indicate a mutual interest in deepening China-Africa investment ties. However, there are also reports of rampant business corruption by Chinese stateowned enterprises in Africa. ${ }^{105}$

Unlike the United States, China does not impose any meaningful constraints on the behavior of its companies in how they conduct business in foreign countries. ${ }^{106}$ In fact, China's only law dealing with the conduct of its companies in foreign countries is Article 164 of the PRC Criminal Law, which provides: "Whoever, for the purpose of seeking illegitimate benefits, gives money or property to any employee ... shall be sentenced ...."107 This law may not serve as much of a deterrent to bribery by SOEs in foreign countries. Although Chinese SOEs now have business operations in many countries abroad, Chinese authorities have not brought a single prosecution since Article 164 be-

26/business/international/chinas-global-ambitions-with-loans-and-strings-attached .html?mcubz=3 [https://perma.cc/Z7GZ-6TEK].

100. The Scale of Corruption in Africa, Economist (Dec. 3, 2015), https://www .economist.com/news/middle-east-and-africa/21679473-gloomy-news-transparency-in ternational-scale-corruption-africa [https://perma.cc/2NLC-K8XD].

101. See Forum on China-Africa Cooperation, FOCAC (July 18, 2012), http://www .focac.org/eng/dwjbzjjhys/t952503.htm [https://perma.cc/TWY8-U8ND].

102. Lovemore Chikova, Africa: Exploring the China-Africa Development Fund, FOCAC (Oct. 14, 2016), http://www.focac.org/eng/zxxx/t1405739.htm [https://perma .cc/FC36-ZDHG].

103. Kenneth King, The Beijing China-Africa Summit of 2006: The New Pledges of Aid to Education in Africa, 43 CHINA REP. 337 (2007), http://journals.sagepub.com/ doi/pdf/10.1177/000944550704300305 [https://perma.cc/NWC7-9HMN].

104. See Implementation of Follow-Up Actions of the Beijing Summit of Forum on China-Africa Cooperation, FOCAC (Oct. 16, 2007), http://www.focac.org/eng/zxxx/ t372569.htm [https://perma.cc/XCZ7-8MDU].

105. See Jeffrey Young, Corruption Concerns Taint Burgeoning China-Africa Trade, VOA (Sept. 1, 2014, 7:00 AM), https://www.voanews.com/a/corruption-concerns-tain-buregeoning-china-africa-trade/2432469.html [https://perma.cc/3QJCVY3C] ("China aggressively pursues and locks in economic opportunities using, according to analysts, suitcases full of cash when it is needed to close the deal. Another tactic used by Beijing is the 'gift' of building and donating public works projects to African states that have raw materials and other things that China wants access to.").

106. Daniel C.K. Chow, How China Uses International Trade to Promote its View of Human Rights, 45 Geo. Wash. Int'L L. Rev. 681, 712 (2013).

107. PRC Criminal Law, supra note 11, art. 164. China enacted Article 164 in satisfaction of its obligations under the UN Convention on anti-bribery. 
came law in $2011 .^{108}$ The reasons why there have been no prosecutions could be due to a lack of knowledge and evidence of unlawful payments. SOEs are operating in developing countries in Africa and Asia and may be making clandestine payments. The PRC has no enforcement authority in these foreign jurisdictions and local authorities may not have an interest in pursuing these cases. Under these circumstances, PRC authorities might be unable to discover these cases in order to bring a prosecution-even if these prosecutions were a high priority. The foreign location of these cases, the evidentiary problems, and an inability of enforcement in the PRC are all factors indicating that foreign bribery might escape prosecution in the PRC under the Criminal Law.

While PRC law may not deter Chinese entities from engaging in corrupt activities abroad, such activities may fall within the scope of the FCPA. Corruption could also give rise to new FCPA cases in countries where Chinese SOEs are aggressively pursuing business opportunities. This can arise in one of two scenarios. First, Chinese SOEs that have securities listed on a public stock exchange in the United States fall within the jurisdiction of Section 781 of the FCPA that applies to issuers. ${ }^{109}$ Chinese SOEs are increasingly seeking to raise capital in the United States by registering their securities that are then sold on U.S. stock exchanges. ${ }^{110}$ Suppose that an issuer SOE has operations in a developing country and makes a bribe in that country that violates the FCPA. Section 78dd-1 of the United States Code subjects all issuers to its anti-bribery provisions. ${ }^{111}$ Section $78 \mathrm{dd}-1$ provides that an issuer or any "officer, director, employee[,] or agent of such issuer" that makes a bribe to a foreign official to obtain business violates the FCPA. ${ }^{112}$

Numerous accounts in the field indicate that Chinese SOEs are notorious for giving bribes in foreign nations as part of doing business. ${ }^{113}$ In May 2017, the SEC issued a subpoena to Sinovac Biotech Ltd., a

108. Daniel C.K. Chow, Rising Nationalism: China's Regulation of Investment Trade, China's Global Engagement: Cooperation, Competition, and InfluENCE IN THE 21st Century 67, 84 (Jacques deLisle \& Avery Goldstein eds., 2017).

109. See Daniel Margolis \& James Wheaton, Non-U.S. Companies May Also Be Subject to the FCPA, 1 Fin. Fraud L. REP. 168, 170 (2009), https://www.pillsburylaw .com/images/content/2/7/v2/2784/961FAE6040BDB25EB4E6C63B250A3AAE.pdf [https://perma.cc/WB5L-KGPA]. The term "issuer" refers to an entity that "has a class of securities registered pursuant to section 781 of this title and every issuer which is required to file reports pursuant to section $780(\mathrm{~d})$ of this title." 15 U.S.C. $\S 78 \mathrm{~m}(\mathrm{~b})(2)$.

110. See Might Sinovac Become the First Chinese Issuer to Resolve an FCPA Enforcement Action?, FCPA ProfEssor (May 17, 2017), http://fcpaprofessor.com/ might-sinovac-become-first-chinese-issuer-resolve-fcpa-enforcement-action/ [https:// perma.cc/A6B6-E56Z].

111. 15 U.S.C. $§ 78 d d d-1(a)$.

112. Id.

113. See, e.g., Andrew Higgins, Chinese Company Ensnared in Kickback Scandal in Philippines, WAsH. Post (June 24, 2012), https://www.washingtonpost.com/world/ 
Beijing-based company with shares traded on NASDAQ, for documents related to an alleged bribe made by Sinovac to obtain drug approvals in China from the China Food and Drug Administration. ${ }^{114}$ The subpoenaing of these documents could be the first step in an FCPA investigation. ${ }^{115}$ In August 2017, both the SEC and the DOJ opened an FCPA investigation into whether China Petroleum \& Chemical Corporation, one of China's largest SOEs and a registered issuer of U.S. securities that trades on the New York Stock Exchange, paid Nigerian officials over $\$ 100$ million to resolve a business dispute. ${ }^{116}$

A second scenario involves cases in which the FCPA applies to foreign persons. Section 78dd-3 of the FCPA states:

It shall be unlawful for any person . . . or for any officer, director, employee, or agent of such person or any stockholder thereof acting on behalf of such person, while in the territory of the United States, corruptly to make use of the mails or any means or instrumentality of interstate commerce ... in furtherance of [a bribe to ... any foreign official ... in order to assist such person in obtaining or retaining business . . . . ${ }^{117}$

The reference to "any person" includes a foreign person. ${ }^{118}$ This provision of the FCPA was designed to subject foreign persons to the jurisdiction of the FCPA as long as such persons have a nexus to the United States. ${ }^{119}$ The statute recognizes that such a nexus exists when the foreign person is physically present in the United States, ${ }^{120}$ even if only on a temporary basis. Chinese SOEs that are not issuers under Section $78 \mathrm{dd}-1$, but that do have a physical presence in the United States and make an illegal payment in a foreign nation, are subject to liability under the FCPA. ${ }^{121}$ For example, suppose that a Chinese SOE has an office or branch in the United States and also a branch in a developing country. This is not a remote scenario, as many SOEs are large corporate conglomerates with many branches and related affiliate entities that have a presence in many countries. ${ }^{122}$ The SOE's

asia_pacific/chinese-company-ensnared-in-kickback-scandal-in-philippines/2012/06/

24/gJQAjdYizV_story.html?utm_term=.0924d1b57855 [https://perma.cc/CY64-4S5H].

114. See Might Sinovac Become the First Chinese Issuer to Resolve an FCPA Enforcement Action?, supra note 110.

115. See id.

116. US Probes Chinese Oil Firm over ' $\$ 100 m$ Bribe Paid to Nigerians', VANGUARD (Aug. 31, 2017, 11:07 PM), https://www.vanguardngr.com/2017/08/us-probes-chineseoil-firm-100m-bribe-paid-nigerians/ [https://perma.cc/A6Z5-KKRN].

117. 15 U.S.C. $\$ 78 \mathrm{dd}-3$.

118. See Rollo C. Baker, Foreign Corrupt Practices Act, 47 Am. Crim. L. Rev. 647, 657-58 (2010).

119. 15 U.S.C. $\$ 78 \mathrm{dd}-3$.

120. See id. (unlawful for any person "while in the territory of the United States" to make an illegal payment).

121. See id.

122. See Liyan Chen, 2015 Global 2000: The Largest Companies in China, Forbes (May 6, 2015, 9:35 AM), https://www.forbes.com/sites/liyanchen/2015/05/06/2015- 
branch office in the foreign nation pays a bribe to a foreign official in return for obtaining business. The presence of the SOE's other branch office in the United States could subject the SOE to FCPA liability for the payment in the developing country. This scenario could also trigger liability under Section 78dd-3 of the United States Code.

Given the aggressive pursuit of business opportunities by SOEs in developing countries and their ability to operate largely outside the purview of the current anti-corruption campaign, SOEs may continue to engage in corrupt activities abroad. Although these cases may not result in prosecution in the PRC, a case involving Chinese SOEs might trigger liability under the FCPA. Cases involving Chinese SOEs that make illegal bribes might also ensnare U.S. persons or firms. For example, U.S. nationals working for a branch office of the SOE in the United States or for third parties such as accounting or law firms hired by the SOE might also be subject to an FCPA investigation.

\section{CONCLUSION}

China's anti-corruption campaign has drawn worldwide media attention. This Article is a study of the effect of the campaign on deterring FCPA cases in China from arising in the future. One might assume that the Chinese government's campaign against corruption would also deter cases from arising under the FCPA, but the situation is more complex. While the purposes and scope of the current campaign overlap in part with those of the FCPA, the current campaign also promotes other important political goals for China's current leader, Xi Jinping. These goals are to protect the Communist Party from embarrassment and to reinforce its power.

China's current campaign focuses on the payment of money or property to Party and government officials. The crackdown seems to be instilling fear and concern among Party and government officialsespecially in rivals of the current leader, Xi Jinping. This development suggests that FCPA cases based on bribes given in the form of money or property to Party or government officials may decrease in the near future. Party and government officials may avoid accepting large gifts of money or property for fear of prosecution by Chinese authorities.

However, China does not have much interest on petty corruption cases involving private persons. These cases do not appear to threaten the Party's reputation and most people in China accept petty corruption as a reality of doing business. There is a special political and social problem involving doctors working at state hospitals. China has long-tolerated kickbacks given to these doctors by pharmaceutical companies, but the recent GSK case embarrassed the Party by the sheer size and audacity of the kickback scheme, which totaled $\$ 500$

global-2000-the-largest-companies-in-china/\#44ffd05a1fbd [https://perma.cc/XB9V6XGC]. 
million in bribes. Although the scheme embarrassed the Party, they still have an incentive to tolerate the kickbacks because they supplement the meager compensation that state doctors receive. While China's current anti-corruption campaign might still tolerate these types of kickbacks, the DOJ and SEC may bring FCPA actions against the MNC pharmaceutical companies because the kickbacks given by MNCs to doctors fall within the definition of bribes given to foreign officials to obtain business.

China's crackdown is focused on gifts of money or property, not intangible benefits. The relevant PRC laws are explicit that gifts of intangible benefits to Party and government officials are not illegal. These laws may reflect China's cultural belief that there is nothing ethically or morally wrong with receiving an intangible benefit in exchange for a favor by a Party official. Thus, a Party official might ask an MNC to hire a company owned or managed by a relative. No direct money or property is given to the Party official, only the intangible benefit of having helped a relative or friend. However, the FCPA's proscription captures not only gifts of money or property, but also "anything of value," a term that is broad enough to encompass gifts of intangible benefits. While China's crackdown may not deter gifts of intangible benefits, these cases may trigger liability under the FCPA.

China's campaign is focused on what occurs within China because that is the activity that directly threatens the Party. China's current campaign does not seem concerned with the activities of China's many powerful SOE's business dealings in other countries. China is in the midst of an aggressive expansion of its business activities conducted by SOEs in parts of the developing world that are already known for corruption and lax enforcement of laws against bribery. The current crackdown is not likely to deter SOEs from aggressive business tactics that involve giving bribes to foreign governments for the purpose of obtaining business or resolving business problems. China's leaders seem to have scant interest in cracking down on these types of cases. But, many of these cases fall squarely within the FCPA. While China's SOEs may not be subject to prosecution in China, they could be exposed to liability under the FCPA. SOEs that have a nexus to the United States, such as by listing securities on a U.S. stock exchange or by having an office in the United States, become subject to the FCPA's jurisdiction. As China's SOEs continue to expand aggressively overseas, FCPA cases involving China's SOEs may increase in number. U.S. nationals or U.S. businesses such as law firms and accounting firms that work for Chinese SOEs in the United States may become ensnared in FCPA investigations.

This study suggests that the relationship between China's crackdown on corruption within its ranks and the FCPA is not straightforward but complex. While China's anti-corruption campaign may have 
the side effect of deterring some types of FCPA cases in China, other cases may not be affected, and still some cases may in fact increase in number. 
